Prepared in cooperation with the U.S. Fish and Wildlife Service

\title{
Differential Expression Profiles of microRNA in the Little Brown Bat (Myotis lucifugus) Associated with White Nose Syndrome Affected and Unaffected Individuals
}

Open-File Report 2013-1099 



\section{Differential Expression Profiles of microRNA in the Little Brown Bat (Myotis lucifugus) Associated with White Nose Syndrome Affected and Unaffected Individuals}

By D. D. Iwanowicz, L. R. Iwanowicz, N. P. Hitt, and T. L. King

Prepared in cooperation with the U.S. Fish and Wildlife Service

Open-File Report 2013-1099 


\title{
U.S. Department of the Interior SALLY JEWELL, Secretary
}

\section{U.S. Geological Survey Suzette M. Kimball, Acting Director}

\author{
U.S. Geological Survey, Reston, Virginia: 2013
}

For more information on the USGS - the Federal source for science about the Earth, its natural and living resources, natural hazards, and the environment, visit http://www.usgs.gov or call 1-888-ASK-USGS.

For an overview of USGS information products, including maps, imagery, and publications, visit http://www.usgs.gov/pubprod

To order this and other USGS information products, visit http://store.usgs.gov

Any use of trade, firm, or product names is for descriptive purposes only and does not imply endorsement by the U.S. Government.

Although this information product, for the most part, is in the public domain, it also may contain copyrighted materials as noted in the text. Permission to reproduce copyrighted items must be secured from the copyright owner.

Suggested citation:

Iwanowicz, D.D., Iwanowicz, L.R., Hitt, N.P., and King, T.L., 2013, Differential expression profiles of microRNA in the little brown bat (Myotis lucifugus) associated with white nose syndrome affected and unaffected individuals: U.S. Geological Survey Open-File Report 2013-1099, 11 p. 


\section{Contents}

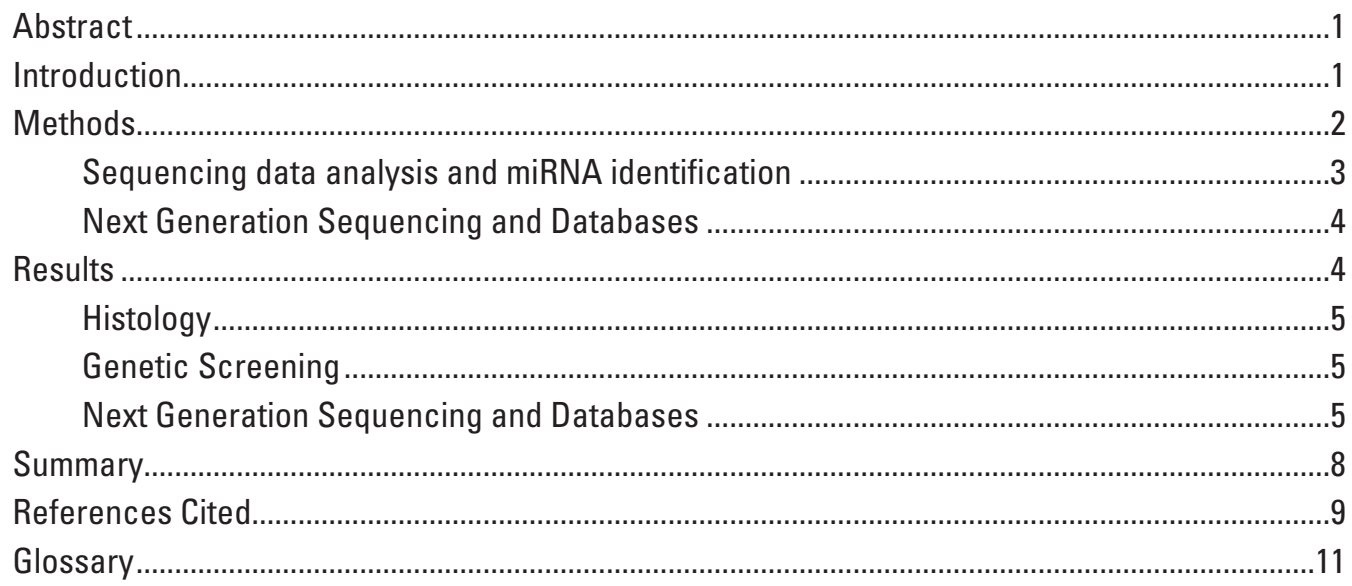

\section{Figures}

1. Representation of small non-coding RNA molecules that are found in the current ENSEMBL microbat non-coding RNA database

2. Internal transcribed spacer polymerase chain reaction analysis of DNA extracted from bat wing biopsy tissue ...............................................................................................

3. Proportional Venn diagram depicting the distribution of unique and common mature miRNA in both the White Nose Syndrome positive treatment group and the WNS-negative treatment group..

4. Statistically significant differences in differentially regulated non-coding RNA between White Nose Syndrome-(WNS) positive and WNS-negative groups.

\section{Tables}

1. General sequencing results and analytical handling of sequence reads for expression analysis with the number of fragments included in RNA-Seq analysis..........5

2. Most abundant mature miRNA detected in the White Nose Syndrome

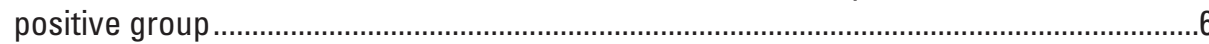

3. Most abundant mature miRNA detected in the White Nose Syndrome

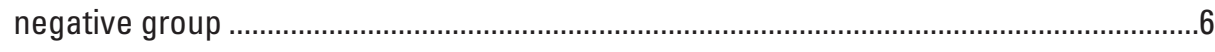

4. Unique miRNA detected in the White Nose Syndrome positive group .............................6

5. Unique miRNA detected in the White Nose Syndrome negative group .............................7 


\section{Conversion Factors and Datum}

\begin{tabular}{lcl}
\multicolumn{1}{c}{ SI to Inch/Pound } & \multicolumn{1}{c}{ To obtain } \\
\hline \multicolumn{4}{c}{ Bultiply } & Length & \\
\hline centimeter (cm) & 0.3937 & inch (in) \\
millimeter (mm) & 0.03937 & inch (in) \\
\hline \multicolumn{3}{c}{ Volume } \\
\hline liter (L) & 33.82 & ounce, fluid (fl. oz) \\
liter (L) & 2.113 & pint (pt) \\
liter (L) & 1.057 & quart (qt) \\
liter (L) & 0.2642 & gallon (gal) \\
liter (L) & 61.02 & cubic inch (in $\left.{ }^{3}\right)$ \\
\hline & Mass & \\
\hline gram (g) & 0.03527 & ounce, avoirdupois (oz) \\
\hline
\end{tabular}

Temperature in degrees Celsius $\left({ }^{\circ} \mathrm{C}\right)$ may be converted to degrees Fahrenheit $\left({ }^{\circ} \mathrm{F}\right)$ as follows:

${ }^{\circ} \mathrm{F}=\left(1.8 x^{\circ} \mathrm{C}\right)+32$

Horizontal coordinate information is referenced to the North American Datum of 1983 (NAD 83) 


\title{
Differential Expression Profiles of microRNA in the Little Brown Bat (Myotis lucifugus) Associated with White Nose Syndrome Affected and Unaffected Individuals
}

\author{
By D. D. Iwanowicz, L. R. Iwanowicz, N. P. Hitt, and T. L. King
}

\begin{abstract}
First documented in New York State in 2006, white nose syndrome (WNS) quickly became the leading cause of mortality in hibernating bat species in the United States. WNS is caused by a psychrophilic fungus, Geomyces destructans. Clinical signs of this pathogen are expressed as a dusty white fungus predominately around the nose and on the wings of affected bats. Relatively new biomarkers, such as microRNAs (miRNAs) are being targeted as markers to predict the syndrome prior to the clinical manifestation. The primary objective of this study was to identify miRNAs that could serve as biomarkers and proxies of little brown bat health. Bats were collected from hibernacula that had tested positive and negative for WNS. Genetic sequencing was completed using the Ion Torrent platform. A number of miRNAs were identified from the liver as putative biomarkers of WNS. However, given the small sample size for each treatment, this data set has only coarsely identified miRNAs indicative of WNS, and further validation is required.
\end{abstract}

\section{Introduction}

White-nose syndrome (WNS) was first documented in New York State during 2006. This syndrome is associated with mortality and morbidity in multi-species of bats in the United States. Since the first description and observation of WNS, increased mortality rates have been reported, and the geographical range of WNS has expanded to include most of the continental United States. This syndrome affects hibernating bat species, including the little brown bat (Myotis lucifugus) and the federally listed Indiana bat (Myotis sodalis). Given the considerable effects that WNS seems to have on such populations, further structured research is imperative to identify at risk populations and develop reliable predictive diagnostic tools.
The disease condition of WNS syndrome is caused by the psychrophilic fungus Geomyces destructans ( $G$. destructans) (Blehert and others, 2009; Gargas and others, 2009; and Lorch and others, 2011), which grows optimally at the low temperatures characteristic of hibernacula. The presence of this pathogen on the wings and nose of affected bats is the hallmark clinical sign of this emerging disease. Originally believed to only occur in eastern North America, G. destructans has recently been identified across Europe (Hayes, 2012; Pikula and others, 2012; Šimonovičov and others, 2011; Puechmaille and others, 2011; Wibbelt and others, 2010; and Martínková, 2010). Although G. destructans clinically manifests on bats in Europe, infections have not been linked to the mortality seen in the United States (Verant and others, 2012). Reasons for the discrepancy have not been determined, but the reasons could be found in the physiological differences in either the bats or the fungus (Hayes, 2012).

A salient aspect of this syndrome is the current geographical range. Although it is suspected that warmer temperatures at southern latitudes may impede the growth of the fungus, the disease is clearly expanding to these areas. To date, WNS has been observed in bat hibernacula in 16 states and 4 Canadian provinces. It is expected that observations of WNS affected bats in other states is likely. In the WNS-affected bat hibernacula, at least seven species of bats have succumbed to mortality from WNS, including the federally endangered Indiana bat (Myotis sodalis). The number of bats killed by WNS is estimated to be more than 5.7 million, with some hibernacula experiencing 100 percent mortality (Froschauer and Coleman, 2012). Bats exhibit unique life-history characteristics that make them very susceptible to this type of population decline (social community structure, longevity, low fecundity). Given the geographic scale of WNS, it is clear that a better understanding of WNS requires a concerted multidisciplinary research approach that considers the community structure of the host, the host environment (hibernacula), microbial community structure (pathogen and other microbes), and putative biomarkers. 
Colonies of little brown bats, either affected or unaffected by WNS, have been identified by the U.S. Fish and Wildlife Service (USFWS) and state wildlife management agencies. Regardless of the cause of WNS, bats affected or unaffected by this syndrome (clinical or preclinical) are physiologically different from each other by virtue of this disease or other predisposing factors. Non-invasive comparative physiological examination of these bats is likely to reveal differences indicative of the problem, presumably leading to the development of predictive markers of the syndrome prior to clinical manifestation.

Biomarkers are commonly exploited in human and animal health as indicators of normal physiological or pathological conditions. Recent discoveries and advances in molecular biology have identified a unique class of regulatory molecules that have the potential to revolutionize diagnostic research (Gilad and others, 2008). These molecules termed small RNAs are a class of small single-stranded noncoding RNAs (about 18-30 nucleotides in length) that essentially function by silencing genes at the transcriptional or post-transcriptional level and, therefore, ultimately regulate the synthesis of gene products (Hamilton and Baulcombe, 1999; Birchler and Kavi, 2008). Small RNAs have been identified in animals, plants, and viruses. The wealth of multispecies microRNAs (miRNAs) has led to the development of a functional database, miRBase, which contains data on more than 17,000 distinct mature miRNAs from over 140 species (Kozomara and Griffiths-Jones, 2011). Bioinformatics and cloning studies estimate that miRNAs may regulate 30 percent of all human genes (Wang and others, 2007). Many studies have determined that individual miRNA's may play pleiotropic physiological roles (Jenkins and others, 2012). Profiles of miRNA expression have been used successfully as biomarkers of physiological conditions, such as pregnancy (Gilad and others, 2008) and abnormal conditions, including cancer (Waldman and Terzic, 2007; Mitchell and others, 2008; and Tanaka and others, 2009).

The primary objective of the investigation, conducted by the U.S. Geological Survey in cooperation with the U.S. Fish and Wildlife Service (proposal title "Expanding our understanding of White Nose Syndrome in Little Brown Bats Myopsis lucifugus"), was to identify miRNAs that could serve as biomarkers or proxies of little brown bat physiological condition and health. More specifically, the intent was to identify miRNA biomarkers indicative of little brown bat populations at risk for WNS. A number of hepatic miRNAs and other small noncoding RNAs (ncRNAs) associated with hibernating bats with or without clinical WNS have been identified. A few candidate biomarkers have been identified, but require further validation for field application.

This report presents a discussion of the methods used to investigate the presence or absence of WNS and a fungus in little brown bats in three types of hibernacula. Discussion of the results includes descriptions of histology and genetic screening. Next generation sequencing and databases also are discussed.

\section{Methods}

The proposed experimental design for this project included the collection of samples across a similar longitude (1) in caves that exhibited no signs of WNS (Ohio), (2) with WNS in the area but not in the cave sampled (Pennsylvania), and (3) in WNS infected hibernacula (New Jersey). The goal was to sample 10 to 15 bats collected at each hibernaculum. Sampling times were to include (1) during hibernation, (2) during early arousal (early winter), and (3) during early spring at the end of hibernation. Additionally, all sampling methods were proposed to be non-lethal and minimally invasive (for example, samples of blood and guano). This sampling regime would provide 45 bats per cave and the subsequent knowledge of the best time to collect bats for miRNA detection. Because of conflicts with cave closings and the inability of the USFWS, state agencies, and non-governmental organizations to assist in these collections as initially proposed, the experimental design was modified to include only two caves with only five bats collected from each cave, as required by the cooperators.

WNS-positive bats were collected from Snow Top Mountain Mine near Wampum, Pa., (4053'01'N 80²0'44”W) in late December 2010. WNS-negative bats were collected at Bowden Cave, Randolph County, W.Va., (38 54'31'”N $70^{\circ} 42^{\prime} 35^{\prime \prime}$ W) in January 2011. Bowden Cave became positive for WNS in March 2011, and five more samples were collected in April 2011 to evaluate subsequent changes in expression. Regardless of the site, bats were collected in the morning, and bagged and processed outside of the hibernacula. Five bats were removed at each sampling (total of 15 bats for the study, $\mathrm{n}=5$ per collection). Bats were euthanized with a lethal dose of isoflurane (a cotton ball soaked in isoflurane was placed in a 50-milliliter $(\mathrm{mL})$ conical tube; bats were individually placed in each tube) (AVMA, 2007). Bats remained in their respective tubes until no sign of life was evident. After bats were euthanized, the sex was recorded and three punch biopsies from the wings were collected and preserved in 95-percent ethanol. Blood collection was attempted by cardiac puncture; however, sufficient blood could not be collected from these hibernating animals for later use. Consequently, blood samples were successfully obtained only from the April collection. The collection of urine and feces samples were attempted from a number of bats, but again, such samples were not reliably obtained from hibernating bats. Pieces of liver, spleen, and lung were removed and placed in RNA Later ${ }^{\circledR}$ for molecular analyses. Carcasses were fixed in Z-fix and archived for histological evaluation. Tissues were processed for histology, embedded in paraffin, cut into 6-micrometer sections, and stained with hemotoxylin and eosin. Periodic acid-Schiff stain (PAS) was used to identify the presence of $G$. destructans.

Genetic screening for $G$. destructans (5 isolates from each site) was based on the ribosomal RNA gene internal transcribed spacer (ITS) region. Briefly, DNA was extracted from the 2 milligrams ( $\mathrm{mg}$ ) of an ethanol fixed wing biopsy 
using the Qiagen DNeasy Tissue Kit (Valencia, California) and stored at 4 degrees Celsius $\left({ }^{\circ} \mathrm{C}\right)$ prior to amplification. Forward and reverse primers and methods used for polymerase chain reaction (PCR) amplifications targeted G. destructans sequences and followed those of Lorch and others (2010). In this study, the forward primer nu-SSI (1506)-184-5' Gd (5'-GGGGACGTCCTAAAGCCT-3') and the reverse primer nu-5.8S-144-3'-Gd (5'-TTGTAATGACGCTCGGAC-3') were used. All primers were purchased from Integrated DNA Technologies (www.idtdna.com). The PCR amplifications were conducted in a master mix containing 1 microMolar $(\mu \mathrm{M})$ of each primer, 1 microliter $(\mu \mathrm{L})$ of $\mathrm{DNA}$, GoTaq ${ }^{\circledR}$ Green Master Mix (Promega, Madison, Wisc.), and nuclease free water. After amplification, $5 \mu \mathrm{L}$ of the DNA sample was identified visually after electrophoresis at 90 volts for 45 minutes (min) in a 1.2-percent agarose gel (I.D.NA ${ }^{\circledR}$, FMC Bioproducts, Rockland, Maine).

Confirmation of the amplicons (pieces of DNA or RNA) as $G$. destructans was achieved using Sanger sequencing in which PCR products were cleaned with a Qiagen PCR Purification kit (Valencia, Calif.). Cycle sequencing conditions were 25 cycles at $96^{\circ} \mathrm{C}$ for 30 seconds (sec), and $50^{\circ} \mathrm{C}$ for $15 \mathrm{sec}$, followed by a 4-min extension at $60^{\circ} \mathrm{C}$. Cycle sequencing reactions were performed using Applied Biosystems (Foster City, Cali.) Big Dye Cycle Sequencing Kit, and the reaction samples were cleaned with Agencourt CleanSeq Beads (Beckman Coulter Genomics, Danvers, Mass.). The cleaned samples were sequenced in both directions using an Applied Biosystems 3100 Genetic Analyzer. Consensus sequences were generated using the forward and reverse sequences.

The isolation of miRNA was conducted using the Ambion ${ }^{\circledR}$ mirVana $^{\mathrm{TM}}$ miRNA isolation kit (Life Technologies, Grand Island, N.Y.) as per manufacturer recommendations. A starting mass of 10 milligrams (mg) of liver tissue was used for all samples. Purified miRNA was stored at $-80^{\circ} \mathrm{C}$ prior to preparation for the sample library. All library construction was performed using specific kits and protocols for Ion Torrent (Life Technologies) sequencing. The miRNA was converted to complementary DNA (cDNA) prior to the development of Ion Total RNA-Seq Small RNA Libraries. Briefly, the concentration and quality of miRNA was assessed using the Agilent 2100 Bioanalyzer small RNA kit. For each sample, 100 nanograms (ng) of miRNA was used as the starting template. All samples were hybridized at $65^{\circ} \mathrm{C}$ for $10 \mathrm{~min}$ and $16^{\circ} \mathrm{C}$ for $5 \mathrm{~min}$ and then ligated at $16^{\circ} \mathrm{C}$ for 16 hours. Following ligation, a reverse transcription master mix was added to each sample, incubated at $70^{\circ} \mathrm{C}$ for $5 \mathrm{~min}$, and then $1 \mu \mathrm{L}$ of ArrayScript ${ }^{\mathrm{TM}}$. Reverse Transcriptase was added and incubated at $42^{\circ} \mathrm{C}$ for $30 \mathrm{~min}$. cDNA was purified with the MinElute ${ }^{\circledR}$ PCR Purification Kit (Qiagen, Valencia, Calif.) and eluted with $10 \mu \mathrm{L}$ of elution buffer. Samples were run on a Novex ${ }^{\circledR} 10$-percent TBE-Urea Gel in an XCell SureLock ${ }^{\text {TM }}$ Mini-Cell at 180 volts for 45 minutes. Two samples of gel of 60 to 80 nucleotide (nt) were excised and placed individually into $0.2 \mathrm{~mL}$ PCR tubes. To amplify the cDNA, a PCR cocktail containing $76.8 \mu \mathrm{L}$ of nuclease free water $\left(\mathrm{NF} \mathrm{H}_{2} 0\right), 10 \mu \mathrm{L}$ of 10X PCR Buffer, $8.0 \mu \mathrm{L}$ of $2.5 \mathrm{mM}$ deoxyribonucleotide triphosphates (dNTP) Mix, $2.0 \mu \mathrm{L}$ of Ion 5'PCR Primer, $2.0 \mu \mathrm{L}$ of Ion 3'PCR primer, and $1.2 \mu \mathrm{L}$ of AmpliTaq ${ }^{\circledR}$ DNA Polymerase for a total volume of $100.0 \mu \mathrm{L}$ was added to each tube. The amplification was then run on the following PCR cycling profile: $95^{\circ} \mathrm{C}$ for $5 \mathrm{~min}, 21$ cycles of $95^{\circ} \mathrm{C}$ for $30 \mathrm{sec}$, $62^{\circ} \mathrm{C}$ for $30 \mathrm{sec}, 72^{\circ} \mathrm{C}$ for $30 \mathrm{sec}$, and an extension of $72^{\circ} \mathrm{C}$ for 7 min. Amplified cDNA was purified with the PureLink ${ }^{\circledR}$ PCR Micro Kit (Life Technologies, Grand Island, N.Y.) with a final elution in $12 \mu \mathrm{L}$ of elution buffer. For a final assessment of the yield and size distribution of the amplified DNA, the samples were run on the Agilent ${ }^{\circledR} 2100$ Bioanalyzer ${ }^{\mathrm{TM}}$ Instrument with the Agilent ${ }^{\circledR}$ DNA 1000 Kit (Agilent Technologies, Santa Clara, Calif.). All library concentrations were serially diluted following the equation below before proceeding to template preparation:

[Library concentration in nanoMolar $(\mathrm{nM})] \times\left[\left(5 \times 10^{9}\right.\right.$ molecules $) / * 8.3 \mathrm{nM})] \times\left[18 \mu \mathrm{L} /\left(280 \times 10^{6}\right.\right.$ molecules $\left.)\right]$.

Once the optimal library concentration was determined, the Ion Sphere ${ }^{\mathrm{TM}}$ Particles were prepared and cleaned following the manufacturer's protocol (Ion Torrent, Publication part number 4465884 Rev.B, May 2011). An emulsion PCR was then generated with the following protocol: A denaturing step at $94^{\circ} \mathrm{C}$ for $6 \mathrm{~min}$, followed by 40 cycles of $94^{\circ} \mathrm{C}$ for $30 \mathrm{sec}$, $58^{\circ} \mathrm{C}$ for $30 \mathrm{sec}$, and $72^{\circ} \mathrm{C}$ for $90 \mathrm{sec}$, and then 5 cycles at $94^{\circ} \mathrm{C}$ for $30 \mathrm{sec}$ and $68^{\circ} \mathrm{C}$ for $6 \mathrm{~min}$, with a final hold time at $10^{\circ} \mathrm{C}$ forever. The ion sphere particles were then recovered washed and enriched with Dynabeads ${ }^{\circledR}$ MyOne ${ }^{\mathrm{TM}}$ Strepavidin $\mathrm{C} 1$ beads. Finally the beads were captured, eluted, and transferred to a $0.2 \mathrm{~mL}$ PCR tube and loaded onto the Ion Torrent.

\section{Sequencing data analysis and miRNA identification}

Adapters were trimmed from the resulting sequences and Ion Torrent sequence reads for individual bats were imported into the CLC Workbench analysis software package. Primary analyses included RNA-Seq analyses for each individual using the microbat non-coding RNA (ncRNA) library as a reference scaffold to determine expression levels of miRNA and other ncRNA. At the time of this analysis little brown bat genome (Ensembl, 2012) was sequenced to 7 times coverage. Although the ncRNA library (database) contains data on 3,826 ncRNA molecules, the data are coarsely annotated to the level of small RNA class [for example, miRNA, small nuclear RNA (snRNA), small nucleolar RNA (snoRNA), ribosomal RNA (rRNA, and miscellaneous RNA (miscRNA); fig. 1]. Of these ncRNA, 795 are putative miRNA. This database was selected for the current analysis because it is the only source of authentic little brown bat ncRNA sequences available. By using this database, the consideration of mismatches could be circumvented for the initial analyses. RNA-Seq expression data were reported as reads per kilobase per million mapped 


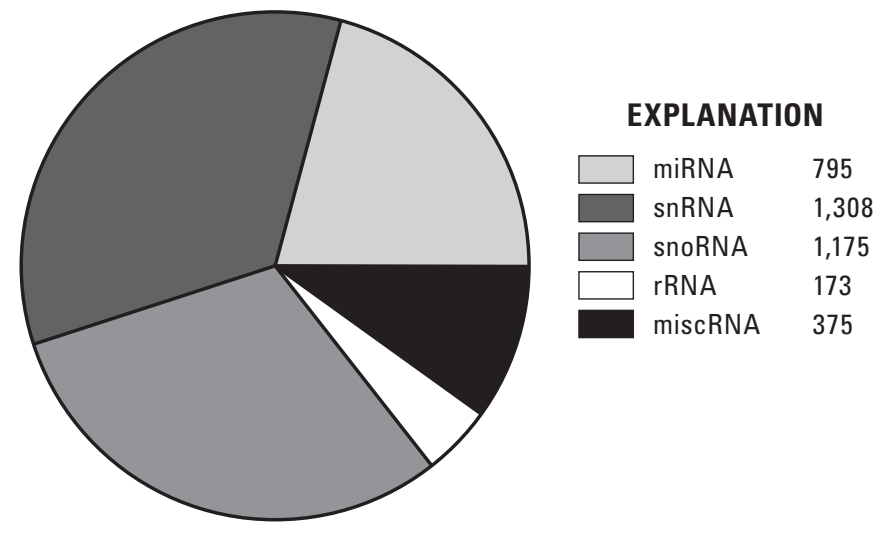

Figure 1. Representation of small non-coding RNA molecules that are found in the current ENSEMBL microbat non-coding RNA database (http://useast.ensembl.org/Myotis_lucifugus/Info/Index).

reads. Values were normalized to the total number of sequence reads from the sample with the least number of reads.

All secondary quantitative analyses were executed using the small RNA workflow in CLC Workbench. Trimmed sequences from individual bats were analyzed using the extract and count procedure. Sequences were excluded from analyses if values were less than $15 \mathrm{nt}$ or greater than $55 \mathrm{nt}$. Additionally, sequences were discarded if they appeared less than three times in a given sequence read. Annotation of the sequences was executed using the "Annotate and Merge" command in CLC Workbench. This procedure used the microbat ncRNA database as the primary database and the miRBase as the secondary database for annotation.

The abundance of miRNAs was compared between bats collected from confirmed WNS-negative, WNS-transitional (prior to WNS-positive determination), and WNS-positive hibernacula. Data were refined to identify the miRNA biomarker candidates. Thresholds for data refinement included analysis of those miRNA that were present only in one treatment group and not the other, or if relative differences in expression were greater than two fold. Differences in expression were expressed as the ratio of median miRNA abundance in WNS-positive bats to that of WNS-negative bats.

\section{Next Generation Sequencing and Databases}

Databases used for quantification and analysis, and annotation, of Myotis lucifugus miRNAs included the ENSEMBL microbat ncRNA database and miRBase (release 18). Approximately 21 percent of the microbat ncRNA database is miRNA (795 unique sequences, fig. 2). The sequences in miRBase used for this analysis included four species, Mus musculus, Bos taurus, Homo sapiens, and Mus domesticus, and the numbers of corresponding miRNA in the database from each were $741,662,1,526$ and 156 , respectively.

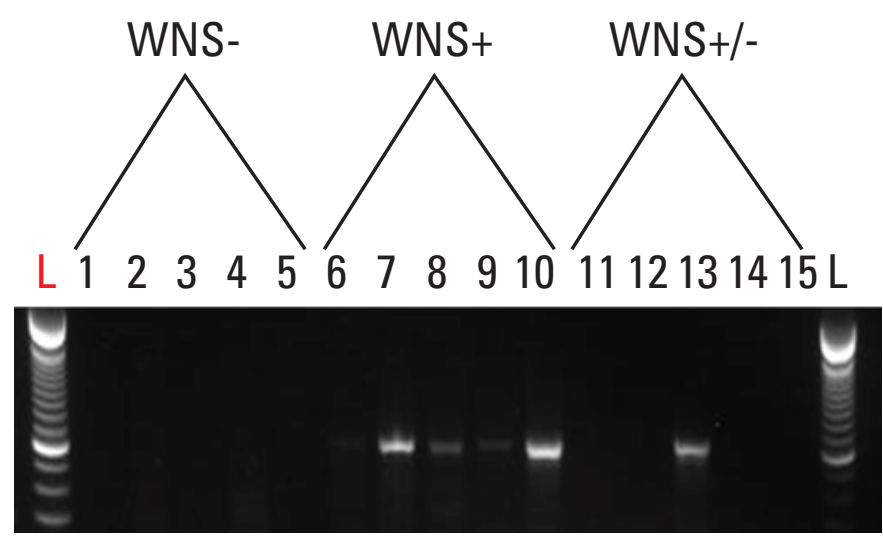

Figure 2. Internal transcribed spacer polymerase chain reaction analysis of DNA extracted from bat wing biopsy tissue. The example is agarose gel images from the three collections of the White Nose Syndrome (WNS) negative group from January 2011(Bowden Cave, Randolph County, West Virginia; 3854'31"N $70^{\circ} 42^{\prime} 35^{\prime \prime}$ ), the WNS positive group from December 2010 (Snow Top Mountain Mine near Wampum, Pennsylvania; $40^{\circ} 53^{\prime} 01^{\prime \prime} \mathrm{N}$ $\left.80^{\circ} 20^{\prime} 44^{\prime \prime} \mathrm{W}\right)$, and the Bowden Cave samples collected in March 2011 (Bowden Cave, Randolph County, West Virginia; 3854'31"N $70^{\circ} 42^{\prime} 35^{\prime \prime}$ W). Products are the amplicons of the Geomyces destructans internal transcribed spacer region of the $18 \mathrm{~S}$ gene; 1.2-percent agarose gel.

MicroRNA from 13 bats was sequenced using the Ion Torrent PGM platform. These analyses were conducted on four bats from a WNS-negative hibernaculum, four bats from a WNS-positive hibernaculum, and five from a tWNStransitional hibernaculum. The status of these hibernacula was based on official status reports by state wildlife managers and was confirmed by PCR analyses (fig. 2). Sequence data for the WNS-transitional hibernaculum are not included in the results here because relevant temporal control treatment was not available.

\section{Results}

Multiple end-points were used to determine the presence of $G$. destructans within the sampled bats, including both histology and PCR amplification and sequencing the rRNAITS region. Histological analysis is considered the standard for diagnosis of G. destructans in WNS and was used in tandem with PCR of the G. destructans ITS region for a multi-tiered confirmation (Lorch and others, 2010).

\section{Histology}

Histological analysis confirmed that bats from Bowden Cave, presumed negative at sampling by local officials, were all negative for $G$. destructans fugal hyphae. Bats from 
Snow Top Mountain Mine that exhibited clinical signs of WNS (white noses and bodies) in the field, however, were also negative by histological analysis (exhibited no fungal hyphae). Interestingly, the bats tested from Bowden Cave in April all exhibited signs of fungal hyphae with a light infection.

\section{Genetic Screening}

PCR of the ITS region of $G$. destructans consistently amplified $G$. destructans specific product in 5 of the 15 bats tested. These bats were from the Snow Top Mountain Cave December 2010 sampling (fig. 2). PCR was repeated six times per individual, and extractions were repeated twice. The five bats that were consistently positive for G. destructans were not found to be positive for WNS by histopathological analysis. This result is atypical to what Lorch and others (2010) found in their research but likely reflect the stage of infection. The five bats collected from Bowden Cave during March 2011were all positive for WNS by histopathological analysis. However, with PCR positive detection was not routinely acquired for all bats. All bats were PCR positive for $G$. destructans for at least one PCR reaction. This very likely reflects a sampling bias for the punch biopsy method and a low grade infection of $G$. destructans, and therefore, a low yield of extracted fungal DNA.

\section{Next Generation Sequencing and Databases}

Approximately 2.7 million reads were obtained from the eight bat samples (four bats from a WNS-negative hibernaculum, Bowden Cave January 2011, and four bats from a WNS-positive hibernaculum, Snow Top Mountain
December 2010) with an average of 337,000 reads per sample (table 1). Sequence reads averaged 66 bases. An average of 123,000 sequences from each sample was utilized in the expression analysis. An Extract \& Count analysis was performed that included each individual sequence read within a treatment group. The resulting data file was subjected to an automated annotation procedure within CLC bio Genomics Workbench using the Mus musculus mature miRNA database within the MirBase v18 database. This analysis yielded 220 mature miRNA. The most abundant miRNA identified in each treatment group are identified in tables 2 and 3, in descending order of abundance. The miRNA unique to each treatment group are listed in tables 4 and 5. The expression of these mature miRNAs appeared to differ between groups (fig. 3). Several miRNAs were identified as being potentially different (fig. 4) on the basis of the Wilcoxin based ranked sum test; however, the sample size was small. The difference in mature miRNAs is very likely an artifact of the small sample size (number of individuals). Given that the samples were not normalized prior to this analysis, inclusion as a unique miRNA does not reflect abundance, and a miRNA was counted if it was identified in as few as one individual in a group. A number of miRNAs and other ncRNAs were identified that were either unique in each treatment group or were present at a significantly different abundance.

A few ncRNAs were identified that were differentially expressed in the liver samples between WNS-positive and WNS-negative groups. These included ENSMLUT00000020579 (putative miR574), ENSMLUT00000021974 (putative miR-2531), ENSMLUT00000021023 (putative miscRNA), ENSMLUT00000018522 (putative snoRD62), and ENSMLUT00000020118 (putative snoRD28; fig. 4). The biological significance of these ncRNAs is largely unknown.

Table 1. General sequencing results and analytical handling of sequence reads for expression analysis with the number of fragments included in RNA-Seq analysis. Much of the sequence data did not correspond to any data in either database.

$[\%$, percent $]$

\begin{tabular}{cccccc}
\hline $\begin{array}{c}\text { Sample } \\
\text { number } \\
\text { of bat }\end{array}$ & $\begin{array}{c}\text { Total sequence } \\
\text { reads } \\
\text { (Thousands) }\end{array}$ & $\begin{array}{c}\text { Count } \\
\text { (Annotated) } \\
\text { (Thousands) }\end{array}$ & $\begin{array}{c}\text { Perfect matches } \\
\text { in miRBase } \\
\text { database }\end{array}$ & $\begin{array}{c}\text { Perfect matches } \\
\text { in ENSEMBL } \\
\text { database }\end{array}$ & Unannotated $^{*}$ \\
\hline 6 & 183 & $18(10.1 \%)$ & $7.7 \%$ & $92.2 \%$ & $89.9 \%$ \\
\hline 8 & 362 & $99(27.4 \%)$ & $17.8 \%$ & $82.2 \%$ & $72.6 \%$ \\
9 & 239 & $19(7.8 \%)$ & $10.4 \%$ & $89.6 \%$ & $92.2 \%$ \\
10 & 475 & $260(54.8 \%)$ & $37.9 \%$ & $62.1 \%$ & $45.2 \%$ \\
\hline 1 & 382 & $253(66.3 \%)$ & $35.2 \%$ & $64.8 \%$ & $33.7 \%$ \\
2 & 436 & $112(25.6 \%)$ & $9.2 \%$ & $90.8 \%$ & $74.4 \%$ \\
4 & 374 & $180(48.4 \%)$ & $25.8 \%$ & $74.2 \%$ & $51.6 \%$ \\
5 & 244 & $39(16.1 \%)$ & $14.3 \%$ & $85.7 \%$ & $83.9 \%$ \\
\hline
\end{tabular}

"Indicates the proportion of total sequences not included in the expression analysis and likely indicates novel small RNAs. 
Table 2. Most abundant mature miRNA detected in the White Nose Syndrome-positive group (Snow Top Mountain Mine near Wampum, Pennsylvania; $40^{\circ} 53^{\prime} 01^{\prime \prime} \mathrm{N} 80^{\circ} 20^{\prime} 44^{\prime \prime}$ W). Identification is based solely on miRBase homology to the house mouse (Mus musculus).

\begin{tabular}{ll}
\hline \multicolumn{1}{c}{ Mature miRNA sequence } & \multicolumn{1}{c}{ Putative identifier } \\
\hline AAACCGTTACCATTACTGAGTT & mir-451 \\
CTGACCTATGAATTGACAGCC & mir-192 \\
TGGAGTGTGACAATGGTGTTTG & mir-122 \\
TGTAAACATCCTACACTCAGCT & mir-30b \\
TAGCTTATCAGACTGATGTTGA & mir-21 \\
TGTAAACATCCTACACTCTCAGC & mir-30c-1//mir-30c-2 \\
CAACGGAATCCCAAAAGCAGCTG & mir-191 \\
AACCCGTAGATCCGATCTTGTG & mir-99a \\
TGTAACAGCAACTCCATGTGGA & mir-194-1//mir-194-2 \\
GTCCAGTTTTCCCAGGAATCCCT & mir-145 \\
TCCCTGAGACCCTAACTTGTGA & mir-125b-2//mir-125b-1 \\
TGAGGTAGTAGGTTGTATAGTT & let-7a-1//let-7a-2 \\
CCCAGTGTTCAGACTACCTGTTC & mir-199a-1//mir-199a-2 \\
TGAGGTAGTAGTTTGTACAGTT & let-7g \\
\hline TAGCAGCACGTAAATATTGGCG & mir-16-1//mir-16-2 \\
\hline TTCAAGTAATCCAGGATAGGCT & mir-26a-1//mir-26a-2 \\
\hline CATTATTACTTTTGGTACGCG & mir-126 \\
\hline TCCCTGAGACCCTTTAACCTGTGA & mir-125a \\
TGTAAACATCCTCGACTGGAAG & mir-30a \\
TGTAAACATCCCCGACTGGAAG & mir-30d \\
\hline
\end{tabular}

Table 3. Most abundant mature miRNA detected in the White Nose Syndrome-negative group (Bowden Cave, Randolph County, West Virginia; $38^{\circ} 54^{\prime} 31^{\prime \prime} \mathrm{N} 70^{\circ} 42^{\prime} 35^{\prime \prime}$ W). Identification is based solely on miRBase homology to the house mouse (Mus musculus).

\begin{tabular}{ll}
\hline \multicolumn{1}{c}{ Mature miRnA sequence } & \multicolumn{1}{c}{ Putative identifier } \\
\hline CTGACCTATGAATTGACAGCC & mir-192 \\
AAACCGTTACCATTACTGAGTT & mir-451 \\
TGTAAACATCCTACACTCAGCT & mir-30b \\
TGGAGTGTGACAATGGTGTTTG & mir-122 \\
TGTAAACATCCTACACTCTCAGC & mir-30c-1//mir-30c-2 \\
TAGCTTATCAGACTGATGTTGA & mir-21 \\
CAACGGAATCCCAAAAGCAGCTG & mir-191 \\
AACCCGTAGATCCGATCTTGTG & mir-99a \\
TTCAAGTAATCCAGGATAGGCT & mir-26a-1//mir-26a-2 \\
TGTAACAGCAACTCCATGTGGA & mir-194-1//mir-194-2 \\
GTCCAGTTTTCCCAGGAATCCCT & mir-145 \\
TAGCAGCACGTAAATATTGGCG & mir-16-1//mir-16-2 \\
TGAGGTAGTAGTTTGTACAGTT & let-7g \\
TCCCTGAGACCCTAACTTGTGA & mir-125b-2//mir-125b-1 \\
CATTATTACTTTTGGTACGCG & mir-126 \\
CCCAGTGTTCAGACTACCTGTTC & mir-199a-1//mir-199a-2 \\
\hline TGTAAACATCCTCGACTGGAAG & mir-30a \\
TGTAAACATCCCCGACTGGAAG & mir-30d \\
\hline TGAGGTAGTAGGTTGTATAGTT & let-7a-1//let-7a-2 \\
TCCCTGAGACCCTTTAACCTGTGA & mir-125a \\
\hline
\end{tabular}

Table 4. Unique miRNA detected in the White Nose Syndromepositive group (Snow Top Mountain Mine near Wampum, Pennsylvania; $40^{\circ} 53^{\prime} 01^{\prime \prime} \mathrm{N} 80^{\circ} 20^{\prime} 44^{\prime \prime} \mathrm{W}$ ). These sequences were not seen in any bats from the White Nose Syndrome-negative cave (Bowden Cave, Randolph County, West Virginia; 3854'31"N $\left.70^{\circ} 42^{\prime} 35^{\prime \prime} \mathrm{W}\right)$.

\begin{tabular}{|c|c|}
\hline Feature sequence & Putative identifier \\
\hline ACAGTACTGTGATAACTGA & mir-101c \\
\hline TACCCTGTAGAACCGAATTTGTG & mir-10b \\
\hline AGGGCTTAGCTGCTTGTGAGCA & $\operatorname{mir}-27 a$ \\
\hline AGGAGCTCACAATCTATTTAG & mir-28b \\
\hline AGGGACGGGACGTGGTGCAGTGTT & mir-92b \\
\hline CGGGGCCGTAGCACTGTCTGA & mir-128-1 \\
\hline AACCGTGGCTTTCGATTGTTAC & mir-132 \\
\hline GCTGGTAAAATGGAACCAAAT & mir-133a-1//mir-133a-2 \\
\hline TATGGCTTTTTATTCCTATGTGA & mir-135a-1//mir-135a-2 \\
\hline TATGGCTTTTCATTCCTATGTGA & mir-135b \\
\hline TAGGTTATCCGTGTTGCCTTCG & $\operatorname{mir}-154$ \\
\hline AACATTCATTGTTGTCGGTGGGT & mir-181d \\
\hline ATGGAGGTCTCTGTCTGACTT & $\operatorname{mir}-1843 b$ \\
\hline TTCCTATGCATATACTTCTTT & mir-202 \\
\hline AGTGGTTCTTGACAGTTCAACA & mir-203 \\
\hline TACTGCATCAGGAACTGACTGGA & $\operatorname{mir}-217$ \\
\hline TGATTGTCCAAACGCAATTCT & mir-219-1 \\
\hline ACTTAAACGTGGTTGTACTTGC & $\operatorname{mir}-302 a$ \\
\hline TGGCCAAGGATGAGAACT & mir-3096 \\
\hline GGGGGGCAGGAGGGGCTCAGGG & $\operatorname{mir}-328$ \\
\hline TTATAAAGCAATGAGACTGATT & mir-340 \\
\hline AGGGGTGCTATCTGTGATTGAG & $\operatorname{mir}-342$ \\
\hline AAAGTGCATGCGCTTTGGG & $\operatorname{mir}-350$ \\
\hline AGATCGACCGTGTTATATTCGC & $\operatorname{mir}-369$ \\
\hline GCGACGAGCCCCTCGCACAAAC & mir-375 \\
\hline AGAGGTTGCCCTTGGTGAATTC & $\operatorname{mir}-377$ \\
\hline TGGTCGACCAGCTGGAAAGTAAT & $\operatorname{mir}-412$ \\
\hline AATGACACGATCACTCCCGTTGA & $\operatorname{mir}-425$ \\
\hline TTTTGCGATGTGTTCCTAATAT & $\operatorname{mir}-450 a-1 / / \operatorname{mir}-450 a-2$ \\
\hline AAGACGGGAGAAGAGAAGGGAG & $\operatorname{mir}-483$ \\
\hline GAAGTTGCCCATGTTATTTTTCG & mir-495 \\
\hline AATCCTTTGTCCCTGGGTGAAA & mir-501 \\
\hline GGAGAAATTATCCTTGGTGTGT & mir-539 \\
\hline AAGTTGCCCGCGTGTTTTTCG & $\operatorname{mir}-543$ \\
\hline TCTTGTTAAAAAGCAGAGTCT & mir-544 \\
\hline TGGTGCGGAAAGGGCCCACAGT & $\operatorname{mir}-675$ \\
\hline TGGTTGACCAGAGAGCACACG & $\operatorname{mir}-758$ \\
\hline CACCACCTCCCCTGCAAACGTCC & mir-1306 \\
\hline CCCCCGAGGAGGACGAGGAGGA & mir-1895 \\
\hline CAGTGGTAGAGCATATGAC & $\operatorname{mir}-1957$ \\
\hline AGCTGCCAGCTGTAGAACTGT & mir-3966 \\
\hline AGCTTGTCTGACTGATGTTG & $\operatorname{mir}-3967$ \\
\hline TAGCTCAGCGGGAGAGCAC & $\operatorname{mir}-5112$ \\
\hline
\end{tabular}


Table 5. Unique miRNA detected in the White Nose Syndromenegative group (Bowden Cave, Randolph County, West Virginia; $\left.38^{\circ} 54^{\prime} 31^{\prime \prime} \mathrm{N} 70^{\circ} 42^{\prime} 35^{\prime \prime} \mathrm{W}\right)$. These sequences were not seen in any bats from the White Nose Syndrome-positive cave (Snow Top Mountain Mine near Wampum, Pennsylvania; $40^{\circ} 53^{\prime} 01^{\prime \prime} \mathrm{N}$ $\left.80^{\circ} 20^{\prime} 44^{\prime \prime} \mathrm{W}\right)$.

\begin{tabular}{ll}
\hline \multicolumn{1}{c}{ Feature identifier } & \multicolumn{1}{c}{ Name } \\
\hline ACATACTTCTTTATATGCCCATA & mir-1a-1 \\
TACATACTTCTTTACATTCCA & mir-1b \\
\hline AGGCAGTGTAGTTAGCTGATTGC & mir-34c \\
GGTTTACCGTCCCACATACAT & mir-299b \\
AGGTGGTCCGTGGCGCGTTCGC & mir-323 \\
AACAATATCCTGGTGCTGAGTG & mir-338 \\
AGCGAGGTTGCCCTTTGTATATT & mir-381 \\
AGGTTGTCCGTGTTGTCTTCTC & mir-494 \\
GCCGGCGGGAGCCCCAGGGAG & mir-2137 \\
GGCGCCGCTCGTGGGGGGCC & mir-5105 \\
\hline
\end{tabular}

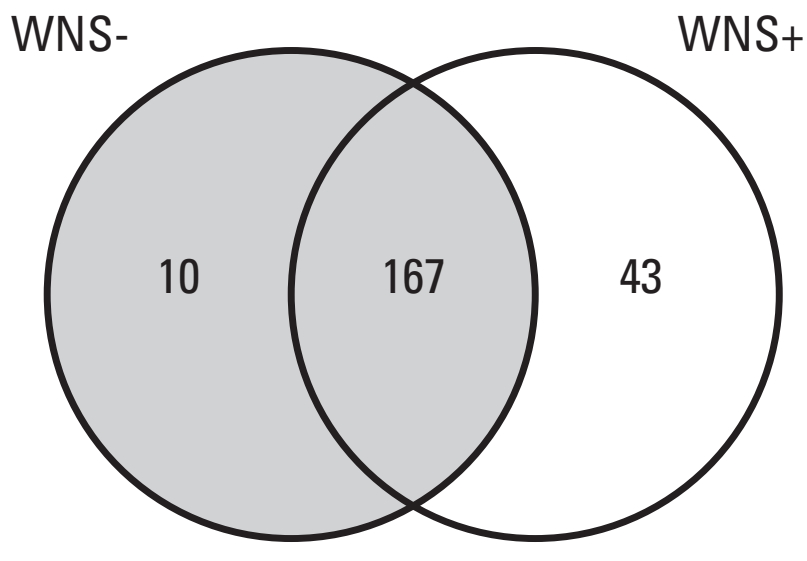

Figure 3. Proportional Venn diagram depicting the distribution of unique and common mature miRNA in both the White Nose Syndrome-(WNS) positive treatment group (Snow Top Mountain Mine near Wampum, Pennsylvania; $40^{\circ} 53^{\prime} 01^{\prime \prime} \mathrm{N} 80^{\circ} 20^{\prime} 44^{\prime \prime} \mathrm{W}$ ) and the WNS-negative treatment group (Bowden Cave, Randolph County, West Virginia; $38^{\circ} 54^{\prime} 31^{\prime \prime} \mathrm{N} 70^{\circ} 42^{\prime} 35^{\prime \prime}$ W). Numbers of the outer areas are the numbers of unique mature miRNA found in individual groups; the number in the center is the number of common mature miRNA found in both the positive and negative WNS groups.

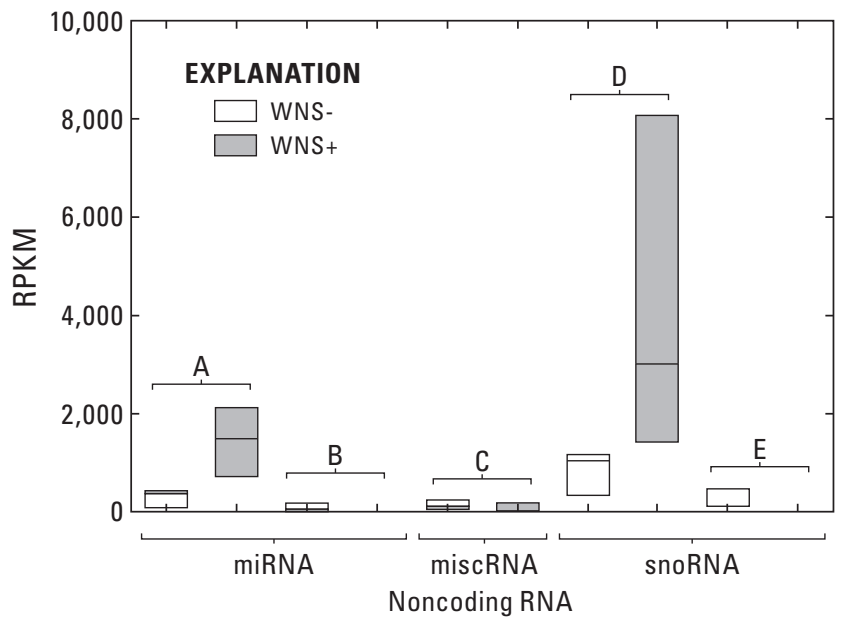

Figure 4. Statistically significant differences in differentially regulated non-coding RNA between White Nose Syndrome(WNS) positive (Snow Top Mountain Mine near Wampum, Pennsylvania; $40^{\circ} 53^{\prime} 01^{\prime \prime} \mathrm{N} 80^{\circ} 20^{\prime} 44^{\prime \prime} \mathrm{W}$ ) and WNS-negative groups (Bowden Cave, Randolph County, West Virginia; 38॰54'31"N $\left.70^{\circ} 42^{\prime} 35^{\prime \prime} \mathrm{W}\right)$. Putative identification of the non-coding RNAs are $A=m i R-574, B=m i R-2531, C=m i s c R N A, D=s n o R D 62, E=s n o R D 28$. Wilcoxon signed-rank test; $p$ is equal to or less than 0.05 . (RPKM, reads per kilobase per million) 


\section{Summary}

The original intent of this research was to identify microRNA (miRNA) profiles indicative of White Nose Syndrome- (WNS) susceptible bat colonies. At the onset of this research, WNS was still an idiopathic disease associated with G. destructans. Given that fungi are rarely primary pathogens, it was hypothesized that bat colonies were susceptible as a result of an altered physiological status and that the physiological regulatory environment could be used as a proxy to identify such individuals or populations. The original proposed sample design included the collection of bats from similar latitudes extending westward to locations where WNS had not been documented. Those proposed hibernacula were defined as (1) confirmed WNS-infected hibernacula (New Jersey), (2) WNS present in the area but not in the sampled cave (Pennsylvania), and (3) WNS-negative hibernacula (Ohio). The goal was to collect 10 to 15 bats at each hibernaculum at multiple time points, including (1) during hibernation, (2) during early arousal (early winter), and (3) during early spring at the end of hibernation. Additionally, all sampling was proposed to be non-lethal and minimally invasive. Target biological samples included body fluids, such as blood and urine. However, because of unforeseen difficulties in the coordination with field biologists to collect samples across the proposed sample range and times, the sample design was modified considerably to coordinate with available field support of field biologists from cooperating governmental agencies and non-governmental organizations. These necessary modifications included limiting the number of sample locations, sample size, and target tissues for analysis, which radically affected the overall expected outcome of the proposed research. However, in spite of these restrictions, the study was still able to identify miRNAs associated with WNS-affected or -unaffected bats. At the present time (2013), it is unknown whether these miRNAs are associated with the diseased condition of affected bats or indicate an underlying physiological status that indicates susceptibility to the fungus.

A few non-coding RNAs (ncRNAs) were identified in this study as putative biomarkers of WNS. Two of these were miRNAs, putative miR-574 and miR-2531. Little is known about the specific functions of these miRs; however, miR-574-5 $p$ has been utilized as a serum-based marker of non-small cell lung cancer in humans (Foss and others, 2011).
Most miRNAs are pleiotropic and affect numerous target messenger RNAs, thus it is possible that this miRNA may be a legitimate biomarker associated with WNS. Because of the limitations associated with the collection of body fluids from hibernating bats (that are generally poorly hydrated), the miRNA expression here reflects that exclusively in the liver. It is possible that these miRNAs are also present in the plasma, but confirmation would require further analysis with appropriate biological samples. Additionally, validation of expression levels of these miRNAs still requires validation using real time PCR(qPCR). Given the small sample size $(n=4)$ for each treatment, the statistical power of the analyses were considerably affected. As a result, this data set has only coarsely identified biomarker miRNA as indicative of WNS, and further validation of this result using a larger sample size is necessary. This work does, however, establish baseline research regarding the identification of little brown bat miRNAs that can be used in future investigations.

Of note, when the sequence data were compared to those within both miRBase and ENSEMBL databases, there were discrepancies regarding the miRNAs identified as potential biomarkers. This likely reflects the novelty of miRNA and ncRNA research and the less than comprehensive comparative databases. Greater than 70 percent of the sequences were not included in these analyses because there were no homologous small RNA data in available databases. Annotation and validation of these novel sequences will take considerable time and effort (years) and was beyond the scope of the current research. It is possible that some of these sequences may serve as biomarkers, but further validation and analysis with adequate sample sizes is necessary.

Since the first identification of WNS in the United States and confirmation of $G$. destructans as the associated primary pathogen, this fungal pathogen has been identified in Europe. More specifically it has been isolated from external samples of bats inhabiting locations in Germany, Hungary, and Switzerland. Of particular note, Europeans bats do not appear to be mortally affected by $G$. destructans. It has been postulated that this suspected resistance is the result of adaptive pressures associated with coevolution and that such bats may be more immunologically or behaviorally resistant compared to the bats in the United States. The miRNAs identified in this study may be useful markers for further comparative analyses designed to rigorously investigate such differences. 


\section{References Cited}

AVMA, Guidelines on euthanasia (formerly Report of the AVMA panel on euthanasia), 2007, American veterinary medical association, accessed December, 27, 2012, at http:// www.avma.org/issues/animal_welfare/euthanasia.pdf.

Blehert, D.S., Hicks, A.C., Behr, Melissa, Meteyer, C.U., Berlowski-Zier, B.M., Buckles, E.L., Coleman, J.T.H., Darling, S.R., Gargas, Andrea, Niver, Robin, Okoniewski, J.C., Rudd, R.J., and Stone, W.B., 2009, Bat white-nose syndrome: an emerging fungal pathogen?: Science, v. 323, no. 5911, p. 227-227.

Birchler, J.A., Kavi, H.H., 2008, Molecular biology. Slicing and dicing for small RNAs: Science, v. 320, no. 5879, p. 1023-1024.

Chan, Stephen; and Loscalzo, Joseph, 2010, MicroRNA-210 a unique and pleiotropic hypoxamir: Cell Cycle, v. 9, no. 6, p. $1072-1083$.

Ensembl. 2012.Wellcome Trust, October 2012, accessed December 27, 2012, at http://useast.ensembl.org/index.html.

Foss K.M., Sima, C., Ugolini, D., Neri, M., Allen K.E., and Weiss, G.J., 2011. miR-1254 and miR-574-5p: serumbased microRNA biomarkers for early-stage non-small cell lung cancer: Journal of Thoracic Oncology, v. 6, no. 3, p. $482-488$.

Froschauer, Anne, and Coleman, Jeremy, 2012, North American bat death toll exceeds 5.5 million from White Nose Syndrome, accessed date at December 12, 2012, at http:// us.vocuspr.com/Newsroom/Query.aspx? SiteName $=$ fws\&En tity $=$ PRAsset\&SF_PRAsset_PRAssetID_EQ $=129322 \& X S L$ $=$ PressRelease $\&$ Cache $=$ True.

Gargas, Andrea, Trest, M.T., Christensen, M.R., Volk, T.J., and Blehert, D.S., 2009, Geomyces destructans sp. nov. associated with bat white-nose syndrome: Mycotaxon, v. 108, p. $147-154$.

Gilad, Shlomit, Meiri, Eti, Yogev, Yariv, Benjamin, Sima, Lebanony, Danit, Yerushalmi, Noga, Benjamin, Hila, Kushnir, Michal, Melamed, Nir, Bentwich, Zvi, Hod, Moshe, Goren, Yaron, and Chajut, Ayelet, 2008, Serum microRNAs are promising novel biomarkers: PLoS ONE, v. 3, no. 9, p. e3148.

Hamilton, A.J., and Baulcombe, D.C., 1999, A species of small antisense RNA in posttranscriptional gene silencing in plants: Science, v. 286, no. 5441, p. 950-952.

Hayes, Mark, 2012, The Geomyces fungi: ecology and distribution: BioScience, v. 62, no. 9, p. 819-823.
Jenkins, Robert; Martin, John; Philliops, Aled; and Fraser, Donald, 2012, Pleiotropy of microRNA-192 in the kidney: Biochemical Society Transactions, v. 40, no. 4, p. 762-767.

Kozomara, Ana, and Griffiths-Jones, Sam, 2011, miRBase: integrating microRNA annotation and deep-sequencing data: Nucleic Acids Research, v. 39, sup. 1, p. D152-D157.

Lorch, J.M., Gargas, Andrea, Meteyer, C.U., Berlowski-Zier, B.M., Green, D.E., Shearn-Bochsler, Valerie, Thomas, N.J., and Blehert, D.S., 2010, Rapid polymerase chain reaction diagnosis of white-nose syndrome in bats: Journal of Veterinary Diagnostic Investigations, v. 22, no. 2, p. 224-230.

Lorch, J.M., Meteyer, C.U., Behr, M.J., Boyles, J.G., Cryan, P.M., Hicks, A.C., Ballmann, A.E., Coleman, J.T.H., Redell, D.N., Reeder, D.M, and Blehert, D.S., 2011, Experimental infection of bats with Geomyces destructans causes whitenose syndrome: Nature, v. 480, no. 7377, p. 376-378.

Martínková, Natália, Bačkr, Peter, Bartonička, Tomáš, Blažková, Pavla, Červený, Jaroslav, Falteisek, Lukáš, Gaisler, Jiř̌̆, Hanzal, Vladimír, Horáček, Zdeněk, Jahelková, Helena, Kolařik, Miroslav, Korytár, L’uboš, Kubátová, Alena, Lehotská, Blanka, Lehotský, Roman, Lučan, R.K., Májek, Ondřej, Matějů, Jan, Řehák, Zdeněk, Šafáŕ, Jiři, Tájek, Přemysl, Tkadlec, Emil, Uhrin, Marcel, Wagner, Josef, Weinfurtová, Dita, Zima, Jan, Zukal, Jan, and Horáček, Ivan, 2010, Increasing incidence of Geomyces destructans fungus in bats from the Czech Republic and Slovakia: PLoS ONE, v. 5, no. 11, e13853.

Mitchell, P.S., Parkin, R.K., Kroh, E.M., Fritz, B.R., Wyman, S.K., Pogosova-Agadjanyan, E.L., Peterson, Amelia, Noteboom, Jennifer, O’Briant, K.C., Allen, April, Lin, D.W., Urban, Nicole, Drescher, C.W., Knudsen, B.S., Stirewalt, D.L., Gentleman, Robert, Vassella, R.L., Nelson, P.S., Martin, D.B., and Tewari, Muneesh, 2008, Circulating microRNAs as stable blood-based markers for cancer detection: Proceedings of the National Academy of Sciences of the United States of America, v. 105, no. 30, p. 10513-10518.

Pikula, Jiri, Bandouchova, Hana, Novotný, Ladislav, Meteyer, C.U., Zukal, Jan, Irwin, N.R., Zima, Jan, and Martínková, Natália, 2012, Histopathology confirms white-nose syndrome in bats in Europe: Journal of Wildlife Diseases, v. 48, no. 1, p. 207-211.

Puechmaille, S.J., Wibbelt, Gudrun, Korn, Vanessa, Fuller, Hubert, Forget, Frédéric, Mühldorfer, Kristin, Kurth, Andreas, Bogdanowiz, Wieslaw, Borel, Christophe, Bosch, Thijs, Cherezy, Thomas, Drebet, Mikhail, Görföl, Tamás, Haarsma, A.J., Herhaus, Frank, Hallart, Guénael, Hammer, Matthias, Jungmann, Christian, Le Bris, Yann, Lutsar, Lauri, Masing, Matti, Mulkens, Bart, Passior, Karsten, Starrach, Martin, Wojtaszewski, Andrzej, Zöhel, Ulrich, and Teeling, E.C., 2011, Pan-European distribution of white-nose syndrome fungus (Geomyces destructans) not associated with mass mortality: PLoS ONE, v. 6, no. 4, p. e19167. 
Šimonovičov, Alexandra, Pangallo, Domenico, Chovanová, Katarína, Lehotská, Blanka, 2011, Geomyces destructans associated with bat disease WNS detected in Slovakia: Biologia, v. 66, no. 3, p. 562-564.

Tanaka, Masami, Oikawa, Kosuke, Takanashi, Masakatsu, Kudo, Motoshige, Ohyashiki, Kazuma, and Kuroda, Masahiko, 2009, Down-regulation of miR-92 in human plasma is a novel marker for acute leukemia patients: PLoS ONE v. 4, no. 5 , p. e5532.

Verant, Michelle, Boyles, Justin, Waldrep Jr., William, Wibbelt, Gudrun, and Blehert, David, 2012, Temperaturedependent growth of Geomyces destructans, the fungus that causes bat white-nose syndrome: PLoS ONE v. 7, no. 9, p. e46280.

Waldman, S.A., and Terzic, Andre, 2007, Translating microRNA discovery into clinical biomarkers in cancer: Journal of the American Medical Association, v. 297, no. 17, p.1923-1925.

Wang, Hui, Ach, R.A., and Curry, Bo, 2007, Direct and sensitive miRNA profiling from low-input total RNA: RNA-A Publication of the RNA Society, v. 13, no. 1, p. 151-159.

Wibbelt, Gudrun, Kurth, Andreas, Hellmann, David, Weishaar, Manfred, Barlow, Alex, Veith, Michael, Prüger, Julia, Görföl, Tamás, Grosche, Lena, Bontadina, Fabio, Zöphel, Ulrich, Seidl, H.P., Cryan, P.M., and Blehert, D.S., 2010, White-nose syndrome fungus (Geomyces destructans) in bats, Europe: Emerging Infectious Diseases, v. 16, no. 8, p. $1237-1242$. 


\section{Glossary}

Bioinformatics The retrieval and analysis of biochemical and biological data using mathematics and computer science, as in the study of genomes.

Clone A cell, cell product, or organism that is genetically identical to the unit or Individual from which it was derived.

Complementary DNA Single-stranded DNA synthesized in the laboratory using messenger RNA as a template and the enzyme reverse transcriptase.

Fecundity Capacity of producing young.

Gene Expression Process by which information from a gene is used in the synthesis of a functional gene product.

Genetic Screening Assessment of an individual's genetic makeup in an attempt to predict genetic predisposition to certain illnesses.

Hibernacula Winter quarters of a hibernating animal.

Histology The structure, especially the microscopic structure, of organic tissues.

Longevity The length or duration of life.

PCR Abbreviation for polymerase chain reaction: a technique for rapidly producing many copies of a fragment of DNA for diagnostic or research purposes.

Putative Commonly regarded as being; supposed.

Ribosomal RNA A type of RNA, distinguished by its length and abundance, functioning in Protein synthesis as a component of ribosomes (abbrev: rRNA).

Salient Prominent or conspicuous.

Sequence To determine the order of (chemical units in a polymer chain), especially nucleotides in DNA or RNA or amino acids in a protein.
Small RNA Term used for short noncoding RNA. There are different classes of small RNAs such as small nucleolar RNAs (snoRNAs), small nuclear RNAs (snRNAs), miscellaneous RNAs (miscRNA). Each class primarily guide chemical modifications of other RNAs.

microRNA Single-stranded RNA molecules of about 21-23 nucleotides in length, which regulate gene expression. 

Prepared by the West Trenton Publishing Service Center.

For more information concerning this report, contact:

Director

U.S. Geological Survey

Leetown Science Center

11649 Leetown Road

Kearneysville, WV 25430

or visit our Web site at:

http://www.lsc.usgs.gov/ 
